\title{
Redefining Economic Sustainability in Resource-rich States: Comparative Lessons
}

\section{Manal Shehabi}

\section{l INTRODUCTION}

In economic development discussions in both policy and academic milieus alike, the term "economic sustainability" has been repeatedly used, but its definition remains elusive. At times, it is implicitly defined, while at others it is defined in terms of economic indicators (such as gross domestic product (GDP) per capita or share of export to GDP). The way the term is used can have various economic foci-such as fiscal, debt, export, and growth sustainability. In the context of "resource-dependent economies"-defined herein as resource-rich states that depend on the exportation of natural resources such as hydrocarbons as a primary source of economic revenue - the issue of "economic sustainability" is also variant and has come to mean different things over time. Initially, economic sustainability was linked to trade theory, and thought to be dependent on the export of natural resources, but that theory failed to achieve the promised growth and development in many resource-rich states-many of which were the world's poorest and most troubled economies. With time,

\footnotetext{
M. Shehabi (四)

Oxford Institute for Energy Studies, Oxford, UK

e-mail: manal.shehabi@oxfordenergy.org

(C) The Author(s) 2021

G. Luciani, T. Moerenhout (eds.), When Can Oil Economies Be

Deemed Sustainable?, The Political Economy of the Middle East, https://doi.org/10.1007/978-981-15-5728-6_7
} 
"sustainability" has changed to reflect the political and economic problems in resource economies. In recent and contemporary discussions, economic diversification has mostly become the dominant recipe for economic sustainability in resource-dependent economies. While diversification is important, adopting policies that focus solely on it fails to reflect the economic performance of these states and the full scope of economic challenges they face. Defining economic sustainability is important to the extent that it affects the design and implementation of economic policy meant to achieve long-term growth and development.

Against this background, this chapter redefines economic sustainability in resource-dependent states. The definition reflects the economic challenges they face due to resource dependence with reference to economic growth theory and by way of a comparative assessment of successful states. First, the chapter summarizes the changing definition of economic sustainability in this context. The chapter then redefines economic sustainability as an issue that needs to be considered from two main perspectives: a volatility perspective and a depletion perspective. The definition then reverts to economic growth theory as a basis for designing sustainabilitypromoting economic policies that take into account both perspectives. A comparative assessment follows, drawing on examples from three main cases: Botswana, Chile, and Kuwait (the primary case study herein).

\section{The Changing Understanding of Economic} Sustainability in Resource States

In its basic form, "economic sustainability" entails continuation of the economy; in the context of resource-dependent states, its definition has substantially changed over time. In the wake of the expansion of the export-led growth economic theory, the dominant driver for economic sustainability in the 1970s (especially in poor countries) was believed to be economic growth achieved by specialized exportations of abundant natural resources. Support for this strategy drew from international trade theories, which proved important in explaining economic performances and business motives.

Export-led growth was based on the concept of comparative advantage, a key driver in economic trade theory. The Ricardian model articulated patterns of and gains from trade in terms of comparative advantage: countries specialize in the activities in which they are relatively more productive. 
The relationship between factor endowment and patterns of trade, known as the Heckscher-Ohlin Theorem, states that a country will have a comparative advantage in, and therefore export, the goods that use relatively intensively that country's abundant factor (Heckscher 1919; Ohlin 1933). Hecksher-Ohlin models are driven by differences in factor intensities across countries, entailing that sustainability in resource-rich states would require exporting natural resources.

Export-led growth shaped development policies of resource states, supported by evidence of a positive relationship between exports and economic growth (such as Michaely 1977; Bhagwati 1978; Balassa 1978; Krueger 1984). Yet such models had shortcomings in explaining actual trade trends, first noted in the US in the 1950s. ${ }^{1}$ Further, export-led growth theory neither predicted weak economic performance in resourcedependent economies (like Bolivia, Nigeria, and Venezuela), nor explained problems they commonly faced (such as lower growth or price and exchange rate volatility). Thus, the validity of the export-promotion hypothesis was challenged (by studies like that of Jung and Marshall (1985)).

Achieving sustainability by exporting natural resources was further challenged following the exposure of surprising political, economic, and developmental realities in resource-dependent states by the exhaustively debated "resource curse" literature in the 1990s (a term coined by Auty (1993) similar to the "paradox of plenty" by Karl (1997)). Since the 1970s, many of these states have underperformed resource-poor countries and failed to achieve expected socio-economic and political development commensurate with their resource wealth. A significant negative relationship is shown to exist between economic growth and the intensity of petroleum and other mineral resources (Sachs and Warner 1995). The curse and various associated elements, such as state intervention, also feature as a common denominator in many political economy models of resource-dependent economies. This counterintuitive situation has been attributed to a host of factors, such as institutional quality (Sala-i-Martin and Subramanian 2003; Bulte et al. 2005), rent-seeking behavior (Gelb 1988; Auty 2001; van der Ploeg 2011), weak public governance, and corruption. Yet no general consensus exists regarding its exact cause.

\footnotetext{
${ }^{1}$ This discrepancy is pointed out by Leontief (1953) in what is known as the Leontief paradox. It refers to the US's exporting labor-intensive commodities and importing capitalintensive commodities despite being the most capital-abundant nation in the 1950s.
} 
Subsequent research emerged extending the neoclassical framework of trade patterns beyond resource endowments and examining determinants of comparative advantage other than the abundance of natural resources. Such determinants include infrastructure (such as transportation), institutions, innovation, macroeconomic volatility, and human capital and education of labor supply (Lederman and Xu 2007). Shortcomings of the resource curse literature have not passed unnoticed. Studies on the relationship between resources and growth (such as Delacroix 1977; Davis 1995; Monzano and Rigobon 2001; Maloney 2002; Wright and Czelusta 2004; Alexīv and Conrad 2009) show inconclusive or no evidence on the resource curse and suggest its literature ignores the natural cycle associated with resource exploitation. Nevertheless, the performance of resource-dependent economies continued to be explained as part of the resource curse, so the understanding of sustainability development changed to entail movement away from resource dependence.

Sustaining exportation of a finite resource is linked to optimal supply, but theoretical predications also have limitations. The leading Hotelling economic theory has influenced countries' supply. It suggests that the (real) resource price should rise over time at the rate of interest that affects producer extraction decisions (Hotelling 1931). Evidence, however, has been found that oil production in existing wells does not respond to price, unlike drilling activity and costs (Black and LaFrance 1998). Hotelling's rule is also found to be neither a sufficient condition for firm-level extraction decisions nor explanatory of entire industries' production levels by linear aggregation of firms' extraction behaviors (Brazee and Cloutier 2006). Moreover, oil exports, most notably by members of the Organization of Petroleum Exporting Countries (OPEC), are impacted by global oil market dynamics and geopolitical factors not accounted for by Hotelling's rule.

In the economics literature, too, interactions of industrialization and economic sustainability have been explained by the "Dutch disease" (Corden and Neary 1982; Corden 1984; Venables and van der Ploeg 2010). The Dutch disease attributes economic problems of resource dependence to adverse effects on non-resource tradable sectors and expansion of non-traded service sectors which result from significant appreciation of nominal (and real) exchange rates (or inflation in countries with fixed exchange rate regimes) following resource exports (Corden 1984, 2012; Corden and Neary 1982; Venables and van der Ploeg 2010; Tyers 2015; Tyers and Walker 2016). Importantly, this "disease" is an economic reality 
of only some sectors and occurs even in successful resource-based economies such as Norway, Canada, and Australia.

Other explanations of distortions in economic structure include poor interindustry linkages that lead to reliance on imported rather than domestic inputs to the resource sector (Tornell and Lane 1999). Another factor may be immiserizing growth-the possibility that a country's export growth for a product is so large relative to the world market that a decline in its terms of trade is caused. There is no obvious reason, however, as to why this phenomenon should occur more due to resource exploitation/ export than the expansion of other export industries. Nonetheless, its existence instigated calls for economic diversification.

Countries that depend largely on resources appeared "unsustainable" due to lack of diversification. Thus, economic sustainability has come to entail (and heavily advocate) diversifying the industrial base and, at times, a reduction of fiscal rigidities, especially given the exhaustibility of natural resources, especially hydrocarbons. Accordingly, many countries (such as oil-dependent Gulf Cooperation Council (GCC) states) adopted developed plans and "visions" that placed diversification at the heart of its longterm goals.

Yet considering economic diversification as synonymous with economic sustainability appears inadequate and confusing at face value. First, the lack of diversification fails to explain the economic challenges faced by resource-dependent economies or the successful economic performance of states like Botswana, Chile, Australia, Malaysia, and Norway. Another example is the GCC states which, despite heavy hydrocarbon dependence, achieved enviable wealth, high measures of per capita income levels, and impressive improvements in socio-economic and human development indicators. Second, diversification is not well defined. Although considered undiversified, GCC states have a sizable share of non-energy sectors in their value added, yet they remain vulnerable to economic challenges, the depth of which has been exposed since the oil price collapse in mid-2014. Further, their export base and government revenue are dominated by the energy sector (hydrocarbons, electricity, and water desalination) with relatively low levels of industrial diversification in exports, as Table 7.1 shows.

Undoubtedly, sustaining an economy is largely facilitated by export diversification, but diversification affects more than exports. Even a closed economy is by definition self-reliant and, therefore, quite diversified; but it is not necessarily sustainable. Its resources are not optimized and its 
Table 7.1 GCC energy sectors, 2014

\begin{tabular}{lccc}
\hline \multirow{2}{*}{ Country } & \multicolumn{3}{l}{ Share of energy sectors (\%) } \\
\cline { 2 - 4 } & In value added & In exports & In government revenue \\
\hline Bahrain $^{\mathrm{a}}$ & 40 & 69 & 83 \\
Kuwait $^{\mathrm{b}}$ & 61 & 91 & 91 \\
Oman $^{\mathrm{b}}$ & 54 & 84 & 79 \\
Qatar $^{\mathrm{d}}$ & 32 & 85 & 90 \\
Saudi Arabia $^{\mathrm{e}}$ & 50 & 80 & 88 \\
UAE $^{\mathrm{f}}$ & 45 & 78 & 60 \\
\hline
\end{tabular}

Notes: Unless otherwise stated, the share in government revenue was based on data reported by the government and may exclude income from oil and gas investments (which were captured in non-energy industries); thus, it may be understated. For United Nations value-added data (2018), sectoral data on the share of non-energy in value added were not available in the national accounts, so UN data for mining, manufacturing (including refining), and utilities were used as proxies. Therefore, these figures may be overestimated. For Qatar, government revenue includes income from oil and gas investments. Sources are listed below. For UAE, the share of energy exports is for 2016

${ }^{a}$ For Bahrain: National accounts and budget from Bahrain Open Portal Data (2018); government budget form Bahrain Ministry of Finance (2018); United Nations value added data (2018)

${ }^{\mathrm{b}}$ For Kuwait: National accounts from Kuwaiti Central Statistical Bureau (2018); government budget form Kuwait Ministry of Finance (2018)

'For Oman: National accounts from Oman National Centre for Statistics and Information (2018); government budget from Oman Ministry of Finance (2015); United Nations value added data (2018)

${ }^{\mathrm{d}}$ For Qatar: National accounts from Ministry of Development Planning and Statistics (2018), Staff Concluding Statement for the 2018 Article IV Mission (2018); International Monetary Fund (IMF) Qatar Country Report (2013)

${ }^{\text {} F o r ~ S a u d i ~ A r a b i a: ~ N a t i o n a l ~ a c c o u n t s ~ f r o m ~ S a u d i ~ G e n e r a l ~ A u t h o r i t y ~ f o r ~ S t a t i s t i c s ~(2018) ; ~ g o v e r n m e n t ~}$ budget from Saudi Arabia Ministry of Finance (2018)

${ }^{\mathrm{t}}$ For UAE: United Nations value added data (2018); UAE Annual Economic Report $(2016,2017)$

welfare is not maximized, rendering its performance possibly worse than if it were open. The point here is that "diversification" is neither a guarantee for sustainability nor assurance for solving problems arising from resource dependency, but meaningful diversification is necessary nonetheless.

A continuously changing understanding of "economic sustainability" is problematic to the extent that it impacts economic policies (locally and those promoted by international organizations, such as the IMF). It threatens the durability and consistency of policy implementation and of development plans intended to manage the resource sector and to achieve long-term economic growth. This problem demands adapting the way economic sustainability is defined and, accordingly, introducing new policies that are consistent over time. This is the focus of the next section. 


\section{Redefining Economic Sustainability}

\subsection{Why a Redefinition Is Required}

Ensuring economic sustainability is a common goal in economic development plans of resource-dependent states. In the wake of inadequacies of existing theories in predicting or solving economic challenges common among them, how economic sustainability is understood needs to be adapted to form the basis of successful economic policy.

Economic sustainability is a complex concept with various elements. Of course, comparative advantage remains a key driver of economic specialization and trade. Beyond that, economic performance is affected by public debt, public investment, economies of scale, technology, transportation costs, and noncompetitive industrial structures. Economic outcomes are shaped by public policy, not only in infrastructure, public investments, industrial policy, and trade policy, but also in taxation, distribution of resource rents among the population, employment, and education. Further, in practice, sustainability assessments and subsequent policy design have tended to be discipline-driven. If economic rigor is divorced from political and/or social analyses, policy becomes myopic and counterintuitive.

While economic diversification is necessary for continuity of the economy, it is insufficient. Setting it as the main sustainability-promoting policy has inadequacies, for the following reasons.

First, diversification is at odds with the theory of comparative advantage. Second, as previously explained, the term is not well defined. Diversification can be pursued in either export, budget, or value-added each of which has separate implications on policy and sustainability. Although most definitions imply export diversification, a closed economy is, by definition, diversified.

Third, successful diversification is constrained by various factors: economic development (resource availability, capital limitations, or economic structure), political development (conflict, government structure, political economy, and oligarchs), or social development (population, health, education levels, and constituencies' requirements). Shehabi (2019) shows that the GCC economies' unique structural constraints and economic distortions, and not the Dutch disease, are the primary reasons for limited diversification of export and government revenues. 
Fourth, as mentioned, the lack of diversification has in the past allowed the realization of economic advantages, at least for the GCC states. It was not until the collapse of the oil price in mid-2014 that the depth of their fiscal and economic challenges was revealed, instigating reforms. Development plans including reforms in energy, rent distribution, industrial or private sector development, and labor are intertwined but can also be contradictory and present trade-offs. Some states even adopted reforms in energy subsidies, human capital development, and resource windfall management; but implementation has been weak and resource sectors continue to dominate the economy.

Fifth, diversification is required not only due to resource depletion, but also due to the lack of sustainability of exports during the life of the resource. Export capacity depends on a petrostate's proven reserves, production capacity, local energy needs, and on world demand for conventional energy sources. Local consumption is key in determining a petrostate's ability to sustain its petroleum exports. Many states have had to shift production to satisfy local demand, ultimately becoming net-importers for a number of years; these include Syria in 2008, Indonesia in 2003, and Egypt in 2012. Others, like Oman and Brunei Darussalam, grapple with export diversification plans as their proven petroleum reserves are expected to run out in 15 and 22 years, respectively. In addition, world demand for and the affordability of conventional sources are threatened by technological advancements and investments in shale oil and gas from one side, and renewable energy from the other. The role of the energy sector in climate change has also led to pressures to reduce consumption of fossil fuels and expand reliance on renewables. These factors have contributed not only to the collapse of oil prices in mid-2014, but also to expectations that low oil prices would persist despite minor recovery. Collectively, these factors increase uncertainty in oil prices and challenge OPEC's historical ability to manipulate prices through controlling supplies.

The role of technology is not to be underestimated; a case in point is the sharp decline of the share of Chile's once-dominant copper industry from the third highest in the world to $4 \%$ of the world's production in 1911 following a failure to keep up with the technological advances of American companies (Collier and Sater 1996: 139).

The sustainability of the revenue of natural resource exports is only a part of the economic sustainability equation. Export sustainability is also affected by exchange rates and constraints on production and pricing decisions in light of domestic demand requirements and export quotas. 
Moreover, resource-dependent economies, both rich and poor, face unique yet common policy challenges, chief among them being the volatility of commodity prices. This volatility harms economic performance and output growth in both petrostates and petroleum-importing countries (Ramey and Ramey 1995; van der Ploeg and Poelhekke 2009). It exposes economies to boom-bust cycles, hampering economic performance and output. These cycles are often accompanied by pro-cyclical (rather than countercyclical) fiscal policy, where governmental expenditures greatly expand during booms and contract during busts. Such tendencies are often further exacerbated by domestic macroeconomic and political instability (Frankel 2011). van der Ploeg and Poelhekke (2009) find that there is a direct effect of resource dependence on growth which is positive, but is often dominated by a negative and indirect volatility effect. Periods of oversupply in the world market that reduce petroleum prices and export revenues expose structural defects in state services, as in Nigeria and Venezuela in 1983 and in Russia in 1998. ${ }^{2}$ More recently, since mid-2014, a 71\% price collapse has caused severe fiscal deficits and real declines in exports, government revenues, and GDP for petrostates. Russia, for example, has suffered a redirection of financial flows and exchange rates instability, ${ }^{3}$ while members of the GCC have faced unprecedented deficits, despite a history of significant fiscal surpluses.

Moreover, the problems faced by resource-rich states are often exacerbated by the political economy of resources and of rent distribution. Although heterogeneous, the experiences of many resource-rich states indicate the widespread use of politically motivated reactionary policies in response to resource price volatility, including price controls, producer subsidies, nationalization, restrictions on foreign participation, and stockpiles. These policies are focused on short-term consequences, rather than on the source of the volatility, and do not reduce the exposure of economies to commodity volatility. Resource dependence is often accompanied by overconsumption during or after booms, and buoyed by policies favoring short-term windfall over long-term benefit.

\footnotetext{
${ }^{2}$ In the case of OPEC, while any one country in the cartel can expand supply and raise its revenue, this is not possible for the group as a whole if the initial production level is jointly profit-maximizing.

${ }^{3}$ This situation has been exacerbated by the international sanctions over the Ukrainian crisis.
} 
Therefore, resource-dependent states face considerable pressures in implementing efficient fiscal policy solutions that reduce cyclicality by harnessing oil rent windfalls during revenue booms to cushion downturns during busts, while simultaneously ensuring efficient allocation of resources and diversification of the revenue base to achieve long-term sustainable growth, development, and employment objectives. Stabilizing resource income and securing non-exhaustible sources of revenue are also important policy objectives. Striking variations in petrostates' economic and political statuses point to the conclusion that economic performance depends upon both preexisting heterogeneous conditions and the quality of policy regimes. For these reasons, redefining economic sustainability considering said challenges is crucial.

\subsection{A Redefinition: Back to Basics}

This section redefines economic sustainability by offering a broader definition launching from the linguistic meaning of "sustainability," both during resource dependence and after the depletion of resource export revenue, and anchored in economic growth theory.

The premise for the redefinition is the following. Sustainability entails continuity of economic activity to achieve continuous growth and development. While revenue from an exhaustible resource is, by definition, unsustainable, a resource industry no matter its size is only one part of an economy. Therefore, the continuity of an economy ought to be ensured and evaluated before the exhaustion of the resource as well as after it. A resource-rich economy with proven reserves lasting for a given number of decades has a "permanent" source of income for that period, which can be sufficient to ensure growth and development for that time. Yet the actual outcome depends on the way export windfalls are used and the economy is managed. As such, economic sustainability can be achieved by continuing to exploit an economy's comparative advantage, but strategically in a manner that extends the length of the resource revenue as well as better manages the resource windfall. At the same time, resource revenue is, by definition, volatile, so managing it requires reducing macroeconomic volatility. In light of resource exhaustibility, sustainability necessitates securing alternative sources of revenue generation in the long run. Both of these can be achieved by various means, one of which is diversification indeed. 
As such, it is argued herein that economic specialization based on comparative advantage is not contradictory to sustainability or economic diversification, and that both concepts are relevant to, but insufficient for economic sustainability in resource-dependent states. Dependence on resources in and of itself is not unsustainable. Instead, the policies adopted to manage this dependence and the ability to maintain income generation from it are what determine the extent to which such resource dependence is sustainable. Economic sustainability must be achieved by managing resource supply, export windfalls, and price volatility, as well as by developing the resource sector and value-adding non-resource industries.

Therefore, I posit that sustainability in a resource-based economy is an issue that has two perspectives: managing the volatility of resource-driven revenue and managing the depletion of the resource and/or its export revenue after the commodity export revenue has been exhausted. Importantly, both perspectives are relevant in the short and long terms, but in the short term the volatility perspective is more relevant while in the long term, depletion is more prominent and can be offset with the accumulation of other assets.

Accordingly, this chapter proposes to consider economic sustainability by designing economic policies that address drivers of economic growth taking into account both the volatility and the depletion perspectives. Indeed, economic sustainability does not strictly entail economic growth. Moreover, the latter in reality is neither simple nor basic. Yet focusing on the drivers of economic growth offers the distinct advantage of evaluating an economy continuously over time rather than during the resource dependence episode or after it only. What follows reverts to the literature on economic growth in an elementary growth model, and then adapts it to reflect resource-export dependence.

\subsubsection{Growth in Theory ${ }^{4}$}

An elementary explanation of growth in resource-dependent states is grounded in the traditional neoclassical growth theory emphasizing gradual, steady growth during which the economic structure remains stable. In the context of the vintage neoclassical growth theory of Solow (1956, 1957), as well as Swan (1956) (and subsequent models), the emphasis is on gradual, steady growth, during which the structure of the economy remains stable.

\footnotetext{
${ }^{4}$ Add reference to annex
} 
In modified versions of the Solow $(1956,1957)$ model that include human capital, ${ }^{5}$ the disparity of income between countries is more effectively captured. The steady growth that manifests with physical and human capital depreciation and population pressure is offset by new investments in physical and human capital, as well as by human capital through education and health, technological growth, and productivity. In this steady state, the respective economy progresses at a long-term, underlying rate of innovation. Newer growth models incorporate a more realistic assumption of economy-wide, increasing returns to scale and endogenous technological changes at a steady rate. ${ }^{6}$ When the economy is shocked (by an event such as a war or a decline in resource price), the concavity of production in physical and human capital ensures that investment exceeds the effects of depreciation and population growth during the transition to a new steady state. This transitional growth performance can be considerably improved if higher savings rates can be mobilized.

In a resource-dependent economy, the production factors which drive economic growth are summarized as physical capital, human capital, natural resource, land and environment, and the residual institutions and technology. For illustration purposes and to account for the exhaustibility of both natural resources and land and environment, these factors will be treated as constant, thus having no impact on the growth rate. Accordingly, to demonstrate the Solow $(1956,1957)$ growth model, this section references an augmented, simplified version to account for both physical capital and human capital, collectively, as capital $(K)$, given that both types of capital accumulate in a similar manner. The model simulates the shock of the advent of war and recovery postwar, as in the case of Kuwait. The Elementary model is described in Appendix 1. In it, the population growth rate $(n)$ matches the labor force and employment growth rates. Knowledge (being labor-augmenting technology; $\theta$ ) grows at a constant exogenous rate. The economy grows at a steady state, in terms of per effective worker $\overline{k_{e}}$.

To simulate the war, a shock is first represented by a large destruction in capital and a significant reduction in population. Initially, output will fall, and the remaining capital falls short of the steady-state level, leaving investment at a level above its capital break-even point, causing growth to

\footnotetext{
${ }^{5}$ For further reading, see Mankiw et al. (1992).

${ }^{6}$ For additional reading, see Aghion and Howitt (1992), Grossman and Helpman (1993), Lucas (1988), and Romer (1986, 1990).
} 


\section{Kuwait's recovery: Capital per effective worker}

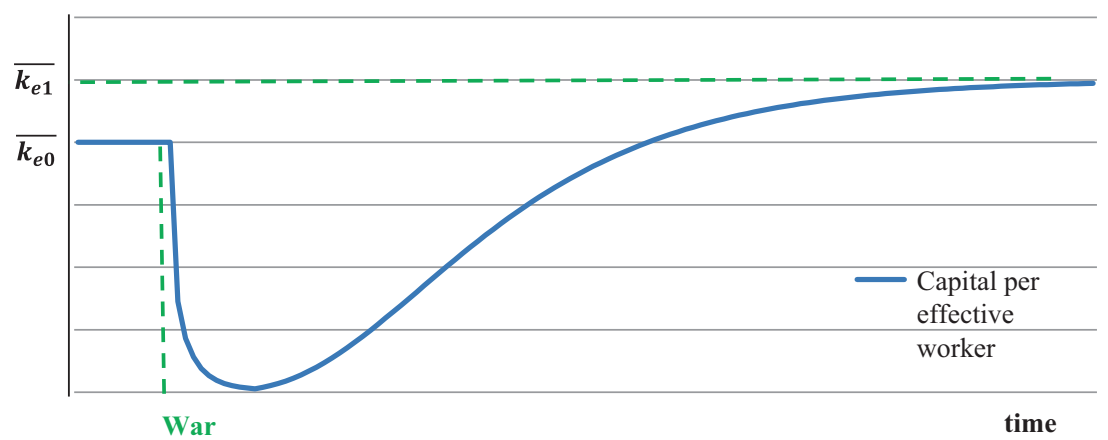

Fig. 7.1 Rapid GDP growth rate at the start of the recovery. (Source: Author's analysis)

increase in the period following the war. This effect is enlarged if the saving rate also rises. The surplus of new investment is then over the breakeven point and larger with an even faster recovery.

As the capital per worker rises temporarily, the productivity of capital increases, inducing a temporarily higher growth rate in the reconstruction (post-shock) phase. Diminished returns eventually return and the growth approaches the long-term path of growth. Additional accumulation of capital during this phase would shift the production possibility frontier curve, reaching a higher level of growth. Similarly, efficiency gains (represented normally as a movement along the production possibility or frontier curve) or higher savings produce new investment surplus over the break-even point, speeding up the recovery.

Upon the end of the shock and at the commencement of recovery efforts, the capital-to-labor ratio converges to pre-shock levels and GDP grows at diminishing rates that were larger than pre-shock levels to eventually converge with pre-shock growth levels, as in Fig. 7.1. The steady state postwar $\left(\overline{k_{e 1}}\right)$ exceeds that prewar $\left(\overline{k_{e 0}}\right)$.

\subsubsection{An Elementary Numerical Simulation}

Notwithstanding shortcomings of the theoretical model, this section demonstrates the impact of sustainability-promoting policies on Kuwait's economic growth postwar through an elementary numerical simulation 
following from the aforementioned theory. ${ }^{7}$ The simulation examines policies that favor capital accumulation (through sovereign wealth fund (SWF) assets), savings and investments, human capital, and technological advancement.

Postwar, Kuwait's economy grew at unmatched speed, owing largely to SWF investment that funded reconstruction. Although a large part of this growth was temporary (reflecting a reconstruction boom), a period of extraordinary growth was driven also by a surge in investment, growth in technology (including that employed in the rebuilding of the oil industry), and an inflow of labor (human capital), mostly of expatriates. A large part of the human capital was maintained and postwar reform focused on increasing the skill set of domestic labor. ${ }^{8}$

To simulate postwar recovery, the capital-to-labor ratio is first shocked. The savings rate is positively shocked to account for faster capital accumulation and further investment in human capital postwar. The rate of technical growth is also positively shocked to simulate the acquisition of knowledge and technical assistance from abroad.

Results show that the rate of output growth $(\mathrm{dY} / \mathrm{Y}$ in Fig. 7.2) was larger than that of capital accumulation. They also reflect the expectation of capital and output growth rate exceeding prewar levels and growing at substantial, yet diminishing, rates and reaching a new higher level of steady-state growth, as Fig. 7.2 shows.

Although the simulation is elementary, its results mirror actual results of the Kuwaiti GDP recovery path postwar. This confirms that Kuwait's postwar growth is partially due to a reconstruction boom, but also partially due to the recovery of capital, human capital, savings, and technological advancement.

\subsubsection{Natural Resources and Technology}

While excluding natural resources is common practice in standard growth models (as in the previous example), examining economic growth in the

\footnotetext{
${ }^{7}$ The rates at which physical and human capital accumulate and depreciate are assumed to be equal for purposes of this illustration. Although not entirely realistic, this assumption is rationalized based upon the low elasticity of Kuwait's output with respect to human capital (0.10), based on 2004 data within the GTAP VIII database for Kuwait.

${ }^{8}$ Additionally, postwar growth in income per capita occurred due to an initially low population because Kuwait had lost close to $40 \%$ of its prewar residents. This growth slowed as the population recovered due to new labor policies until 1997 when the population reached its prewar level.
} 


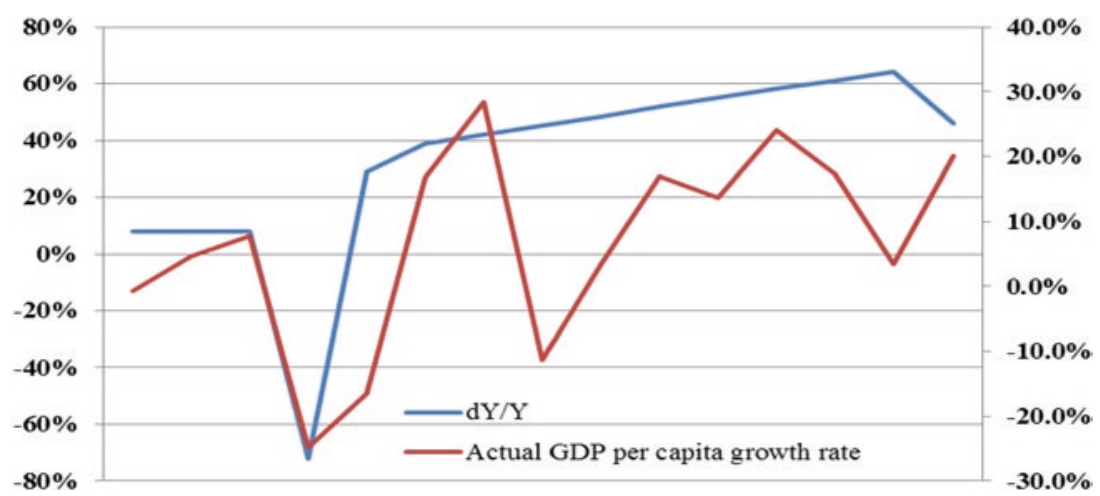

Fig. 7.2 Simulated Kuwait recovery reaching a new steady state due to shocks in capital-to-labor ratio, savings rates, and productivity. (The impact of the war on Kuwait was simulated through the following shocks: (a) an 80\% destruction in physical capital and (b) a $45 \%$ reduction in population. Postwar recovery simulation included a $30 \%$ increase in savings rates, reflecting increased investment in human capital and a doubling of productivity. Output elasticities of capital and labor were calibrated to equal the following values in the GTAP VIII database entry for Kuwait in 2004: 0.75 for capital (being the sum of elasticities of capital and skilled labor of 0.68 and 0.07 , respectively. Source: Author's simulations)

presence of depleted natural resources is consistent with the goals of achieving economic sustainability. As mentioned earlier, economic sustainability entails extending the usable length of the natural resource, which requires ensuring appropriate extraction rates. For demonstration, a simple example is presented, setting the natural resource as the only input of production, and the available resource that can be extracted is a portion of the total available resource value. The mathematical representation to solve this elementary example is expressed in Appendix 1.

If the state of technology is constant over time, the output will eventually become nil when no more of the resource can be extracted. Nevertheless, if the level of technology is allowed to change over time, it counteracts the exhaustibility of the resource. Relaxing the assumption of constant technology, technology is now growing at a constant exogenous rate $(g)$. This set-up enables addressing the question of sustainability: what is the trade-off between producing output today and leaving the resource in the ground for future production? 


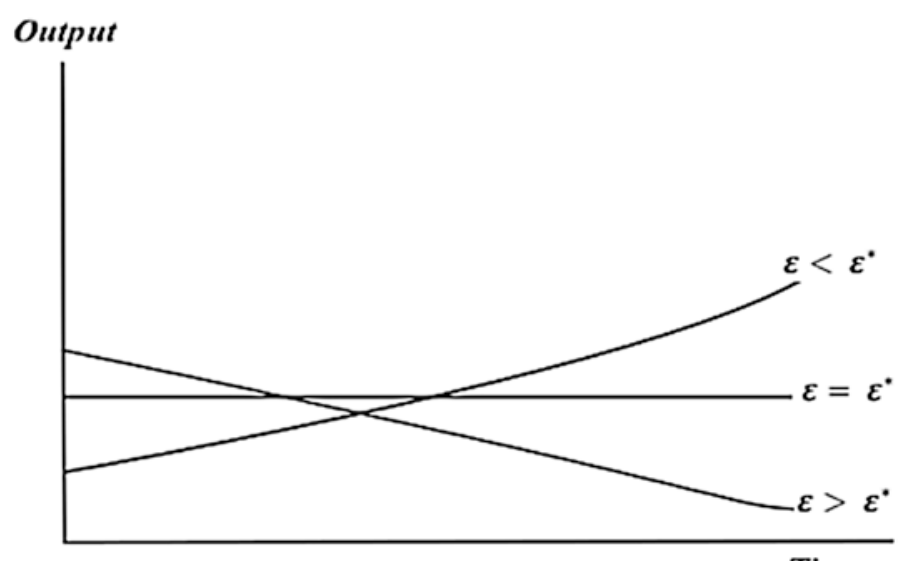

Time

Fig. 7.3 Relationship between resource use and growth

Assuming the resource is extracted at a constant exogenous rate $(\varepsilon)$, the quantity of the remaining resource will decline exponentially over time. Solving the equation yields an extraction rate that is consistent with steadystate levels and a zero growth rate of output, which is $g=\varepsilon^{*}$.

It is clear that there is a positive relationship between the rate of extraction and output: a lower extraction rate would lead to a lower level of output. A higher extraction rate, on the other hand, would lead to a lower growth rate of output, which could even become negative at very high levels of extraction. Setting this value at zero yields an extraction rate that is consistent with steady-state levels and a zero growth rate of output in $\varepsilon^{*}$, which thus represents the sustainable level of output. Therefore, the levels of output in economy can be determined by examining the extraction rate chosen in relations to $\varepsilon^{*}$. If it exceeds $\varepsilon^{*}$, then the initial level of output will exceed the sustainable level, but will decrease overtime, as Fig. 7.3 shows.

Importantly, including the remaining factors of production would complicate the algebraic representation but yield the same general conclusion.

\subsection{The Takeaway}

The theoretical model shows that higher economic growth than that recorded in the previous period (reaching a new steady state) can be achieved by increased savings, increased capital per effective worker, 
improvements in labor productivity, and improvements in labor-augmenting technology to increase economic efficiency. This technology captures the residual of policies that impact economic growth, including but not limited to noneconomic factors - such as institutional quality, legal environments, cultural standards, industrial regulation, and the political economy. Achieving sustainability requires designing policies that address drivers of economic growth while balancing both the volatility and the depletion perspectives, in the short and long runs. This balance is key and difficult as the different terms can have competing interests and trade-offs.

As the theory confirms, there is an intuitive trade-off between producing output today and leaving the resource in the ground for future production, a trade-off that in reality is known and present in the minds of many policymakers, international aid institutions, and citizens of resourcerich states. This is difficult because competition over rent distribution favors faster production, which contributes to larger short-term growth but faster depletion. Yet the model highlights the role of technological progress and its impact on the sustainability of the resource that is already available. Advancements in technology can contribute to efficient extraction as well as extending the length of the available resource and its export revenue.

Another critical factor at the heart of this balancing act is the trade-off between local consumption and exports of a given supply. This is a serious challenge particularly for countries that depend on resources as an important input in production (such as oil being an input in manufacturing or transportation) as well as final demand. In resource-dependent states, the political economy of resources has historically resulted in large government expenditure and financial commitments to fund generous resource rent distribution and guaranteed public employment, which, in turn, have translated into excessive consumption and severe fiscal pressures. The balance between monetary, fiscal, and exchange rate policy is critical in moderating commodity-sourced volatility and in mitigating Dutch disease effects, which is necessary for long-term diversification and sustainability. Technological and efficiency advancement as well as policy reform (at the fiscal, institutional, social, legal, and even cultural levels) are key in moderating domestic consumption and extending the levels of output available for exportation. Striking a balance requires transparent use of resource rents in the short run, and the design and implementation of welfareimproving, productive long-term development. This development can be achieved through policies that focus on (a) human capital development, 
which boosts value added and productivity and can build future industries and knowledge economies; (b) physical capital, which can contribute to industrialization and domestic infrastructure; (c) savings, which can provide new accumulation of assets for the future; and (d) technological advancements, which can contribute to the emergence of new industries and increase efficiencies (like renewable energies, tradable services, and knowledge economies).

\section{Lessons and Comparative Assessments}

For resource-dependent states, navigating resource price volatility demands the best from their economic wealth management and economic policies. Although growth performance of many resource-dependent economies has been poor, a small group of economies have done well, such as Norway, Australia, Botswana, Malaysia, Chile, and the Gulf states. This section highlights comparative successful policy lessons drawing on successful experiences of developing states:

- Chile and Botswana, both states with exemplary performances that avoided the so-called curse

- Kuwait, an example of a GCC state with an enviable economic performance

The subsequent discussion highlights how policies focused on drivers of economic growth and also enabled said states to manage challenges associated with dependence on an inherently volatile and nonrenewable resource, and move toward sustainability.

\subsection{Fiscal Rigor and Savings for Capital Accumulation}

Growth-enhancing policies that consider both perspectives entail managing resource windfalls and accumulating savings and investments for the future; SWFs are a means of achieving these two objectives. SWFs are government-owned investment funds commonly established during periods of government surplus. ${ }^{9}$ They are typically created to serve as stabilization funds, savings funds, pension reserve funds, or reserve investment corporations. In resource-rich states, they are established to reduce the

${ }^{9}$ For further reading, see Collier et al. (2010) and van der Ploeg and Venables (2012). 
impact of volatile petroleum windfall on exchange rates. SWFs also offer a mechanism to reinforce fiscal discipline through rules mandating recurrent contributions to the funds and withdrawal limitations from them. They also offer a mechanism to diversify government portfolios and add new dimensions to foreign assets management. Unlike reserves, SWFs buffer the real exchange rate from terms of trade shocks with fixed exchange rate regimes and in relatively closed economies, with varying results. An IMF study concludes that there is no evidence that fiscal rules have had an effect on fiscal outcomes (Ossowski et al. 2008). Yet among resource economies, the successful cases of Kuwait, Norway, Chile, and Botswana have all had successful SWF experiences.

SWFs are key in achieving sustainability in resource-rich states because they (a) impose fiscal rigor and revenue management; (b) offer savings that can be used in fund development as well as non-resource industries; and (c) save a portion of the resource income in an asset that can be used in the future after the natural resource is exhausted to produce nonresource goods. These factors are drivers of growth in the short, medium, and long terms.

Chile's fiscal constitutions for its copper-based stabilization SWF have been largely successful (Frankel 2011). Chile has had an overall successful experience of resource dependence-unlike its troubled fellow Latin American country Venezuela - which is caused by successful management of resource windfall. Figure 7.4 shows various SWF accumulations of Latin American countries, with Chile being the leader of the pack.

Botswana, a great success story, has delinked the government from current resource revenues, so that revenues that do not meet government spending and investment criteria are invested abroad through Botswana's SWF (IMF 2012).

The role of SWFs is clear in Kuwait's case, which diverts petroleum revenue to external assets invested in its SWF, managed by the Kuwait Investment Authority (KIA). Established in 1953 (eight years prior to independence), the KIA is the oldest country-owned fund in the world. ${ }^{10}$ The KIA managed a fiscal stabilization fund (General Reserves Fund (GRF)) and a savings fund (the Future Generations Fund (FGF)).

Uses of KIA funds can address both the volatility and the depletion perspectives of sustainability, as follows. Either budget surpluses are

\footnotetext{
${ }^{10}$ Predated only by two state-owned funds within the US state of Texas, which were established in 1854 and 1876. It was nearly 20 years before other countries established SWFs.
} 


\section{SWF balances by country}

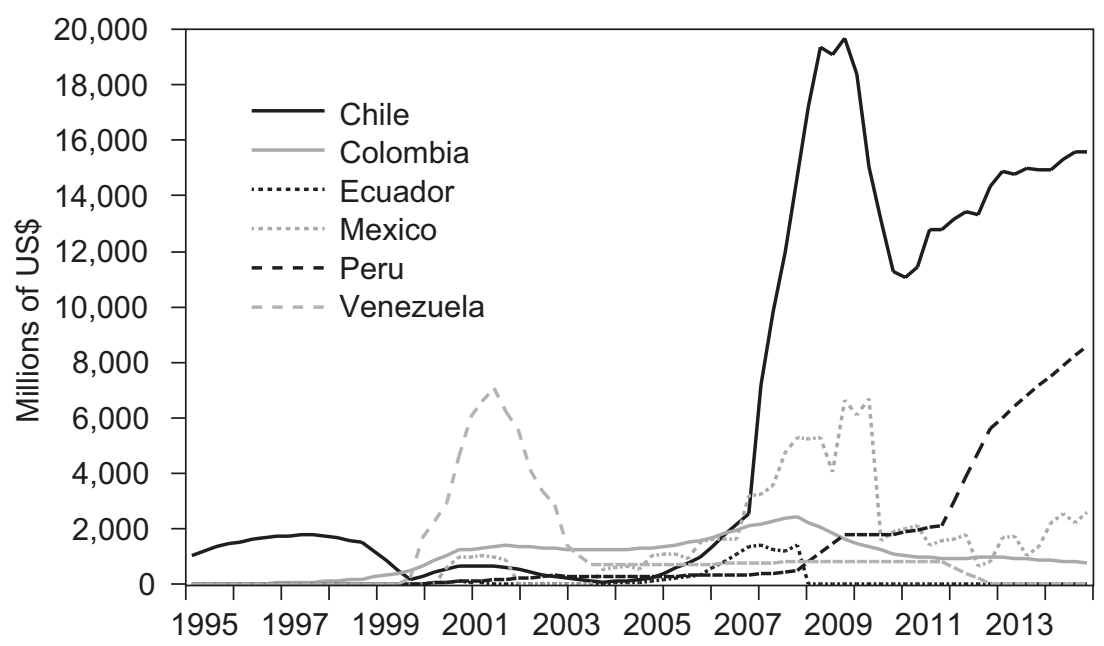

Fig. 7.4 SWF accumulations in select Latin American economies. (Source: Aizenman and Riera-Crichton (2014))

invested in the GRF or funds are withdrawn from it to smooth out shortterm governmental expenditures during deficits, thus shielding the economy from the negative impacts of petroleum price volatility. As for the FGF, Kuwaiti law requires that a minimum of $10 \%$ (increased by an additional 15\% in 2012 and reverted in 2014) of the annual general revenues allocated to this fund are employed by the Ministry of Finance for various investments, with the associated returns and profits also allocated to the same fund. KIA savings created large foreign asset portfolios that acted as an insurance policy to finance capital accumulation and fiscal commitments during low oil price periods. The funds are a primary source of Kuwait's fiscal stabilization. Its funds were invested in ways that diversified revenue sources away from petroleum, hedged oil income risks, and earned interest. In an economy-wide analysis, Shehabi (2017) confirms that revenue inflow from the KIA is a key adjustment mechanism that partially absorbs negative impacts of oil price shocks.

The indispensable role of the KIA in Kuwait's postwar recovery following the Iraqi invasion in 1990-1991 demonstrates the successful role of 
SWFs. The war caused massive destruction of Kuwait's petroleum assets and industry. Funds accumulated in KIA from prewar fiscal surpluses and SWF contributions (estimated at $\$ 25-\$ 50$ billion in $1989^{11}$ ) funded postwar reconstruction (from extinguishing oil-well fires to rehabilitating the petroleum industry). The ensuing petroleum production and exportation allowed the resumption of capital savings.

Despite its advantages, Kuwait's SWF accumulations are juxtaposed against substantial government expenditures and fiscal commitments. One shortcoming is that Kuwait's petroleum windfall has been invested abroad rather than domestically where it could expand industrial capacity ${ }^{12}$ (Shehabi 2019).

The main lesson here pertains to the role of fiscal policy and savings of nonrenewable-resource rents in managing volatile petroleum windfall revenue, shaping economic performance, and providing savings for capital accumulation and development. Such savings can be used for expanding non-energy industries and their exports, and local infrastructure, as well as developing human capital and capabilities for acquiring new comparative advantages.

\subsection{Human Capital}

Investments in human capital are key to successful economic growth. Not only do they improve the performance of resource-dependent economies, but they are also essential for growing the non-resource sector necessary for diversification efforts and managing the depletion perspective. Many of the countries that have experienced the resource curse have missed this opportunity. Meanwhile, countries like Japan and Germany after the Second World War were able to recover despite complete destruction of their economies in part due to the preservation of prewar human capital and the subsequent investments in it.

The role of guest workers in economic development is a key unique feature of the GCC economies. Drawing one example from Kuwait, guest workers represent an important part of these economies' human capital

${ }^{11}$ Due to legal requirements preventing the disclosure of the funds' details, this range is estimated by calculating annual contributions and an estimated low-range return to capital of 2\%. A study by the Arab Planning Institute in 1992 estimated that Kuwait spent approximately $\$ 40-\$ 50$ billion of its foreign investment portfolio on reconstruction.

${ }^{12}$ This is true even during low oil prices when non-energy sectors can theoretically expand (through reverse Dutch disease). 
and are drivers of economic growth and development. A major feature of Kuwait's petroleum economy has been the accompanying spike in population and human capital as expatriates moved to Kuwait on a temporary basis (without a path for naturalization or permanent residency) to fill shortages in some unskilled and mostly skilled human capital given Kuwait's relatively high levels of illiteracy and small population size during the 1970s. ${ }^{13}$ The ability to secure human capital from expatriate labor was also key to achieving postwar reconstruction, as explained earlier (Shehabi 2018a).

Notwithstanding the challenges surrounding dependence on foreign labor, the structure of their labor contracts had an unintended positive outcome on the economy. Expatriate laborers work temporarily in the GCC, with their stay linked to employer-sponsorship programs through the kafala system, and they have flexible labor contracts, often with lower wages than their national counterparts. In model-driven simulations, the expatriate labor exit offers another key stabilization mechanism of the Kuwaiti economy in the face of the volatility of petroleum revenue (Shehabi 2017). The dynamics of the labor market entails different impacts of this contractionary shock on the two labor segments. Typically, as the real wages of expatriate workers are assumed to be sticky (in both the short and long runs), employment levels adjust instead. Since most Kuwaitis are employed by the public sector, where contracts are rigid, their employment is unaffected, while their real wages change slightly. By contrast, the flexibility of expatriate labor contracts allows affected industries to adjust their employment levels, causing similar declines in the employment levels of skilled and unskilled expatriates. The flow of guest workers exponentially increased during oil booms, and decreased during busts. Thus, an example of successful policy includes model-driven policy solutions that focus on the management of labor contracts for expatriate labor (Shehabi 2017). While expatriate labor exit acts as a cushion absorbing oil price shocks, there is a distinct trade-off between efficiency gains from expatriate labor and the goals of Kuwaitization of the labor force

\footnotetext{
${ }^{13}$ The surge in liquidity in the 1970s (owing to booming oil revenues following the 1973 embargo and the nationalization of the petroleum industry) could only be initially accommodated by investments in land, construction, and real estate projects, which required importing a significant number of workers, especially as many Kuwaiti males were not interested in construction-type jobs.
} 
(Shehabi 2018b). Managing this will be important in ensuring future economic sustainability.

Human capital is very important in the sustainability of resource-rich economies because they can contribute to acquiring new comparative advantages. They can create new industries, products, and services. Human capital is also the seed for growth-enhancing innovation and competition.

\subsection{Technology, Institutions, and Taxes}

Technology is undoubtedly a transformative engine and a contributor to growth. In its most traditional definition, technological advancement enhances productivity and efficiency and improves economic performance. In growth theory, as mentioned in the Sect. 3.2.3, technology captures the residual of policies that impact economic growth, including but not limited to noneconomic factors such as institutional quality, legal environments, cultural standards, industrial regulation, and the political economy.

Technology can play an unequivocal role in extending resource export revenue, transform resource industries, and even reverse the threat of depletion and overcome volatility. To demonstrate, the challenges of diminished oil export revenue with climate change mitigation can be alleviated if new technologies enable oil exporters to continue to export energy that is green and adaptive to changing demand trends in the oil market. Such technologies include investments in energy efficiency, carbon capture and storage, and hydrogen. This is an opportunity for oil exporters given their existing comparative advantage and specialization in energy.

Undoubtedly, institutions (part of the overall "technology" driver of growth) are important to securing sustainable long-term economic growth. Botswana offers a success story in striking institutional quality that is favorable to growth. It has not only achieved democratic progress with transparency in rent distribution, but has also affected the development of the resource sector. Instead of the commonly used auctions, Botswana negotiated rights to diamond extraction with the single dominant market player De Beers (Venables 2016; Besada and O'Bright 2018). In doing so, Botswana was able to avoid the lack of competitiveness and transparency, as well as a limited state's share of revenue that would have resulted from awarding the auction to a single market player. The country was also successful in attracting foreign direct investment, thus achieving 
economic diversification while also promoting linkages (Besada and O'Bright 2018). Further, Botswana's institutional quality is recognized by Mehlum et al. (2006), who find negative (and larger) effects of resourcerichness on growth only for economies with poor institutional quality, with the break-even point being around the institutional quality of Botswana.

Taxation is another crucial factor. Norway, Australia, and Canadaresource-dependent states that are considered successful-have sophisticated tax systems (personal, corporate, indirect, and international taxes). These taxes offer a source of government revenue that serves three purposes: increasing the size of non-energy contribution to government revenue; offering additional sources of revenue that can be used to fund current or capital expenditures and public infrastructure; and reducing the need to withdraw from SWF assets during times of fiscal pressures. Taxation and low subsidies are necessary for economic sustainabilityalthough difficult to achieve from a political economy perspective in many resource-dependent states.

\subsection{Industrial Reform and Regulation of Oligopolies}

While regulation is a part of institutions and, therefore, of the larger "technology" growth driver, regulation of oligopolies merits its own distinct discussion. This is due to its unequivocal role in ensuring competition, efficiency, long-term creative destruction, and economic growth. In assessing efficiency and economic policy, the role of oligopolies is critical. Oligopolies exist in almost all countries, including the most advanced ones. Some industries, such as utilities and communications, are also naturally oligopolistic because they require very large fixed costs to be established and require large scales to run them. In small resource-dependent economies, it is not surprising that the high levels of minimum efficient scale delivered by modern technology and the smallness of these economies should lead to the emergence of oligopolies or monopolized industries, particularly in protected services.

Nevertheless, these oligopolies can play a detrimental role in economic sustainability. It has been accepted in economic theory that competition induces innovation and, therefore, economic growth through the process of "creative destruction". This process, coined by Schumpeter, entails an ongoing process in which innovation is induced by competitive forces and destroys rents conferred in the short term by former innovation, 
maintaining efficiency (Schumpeter 1942: 82-83). Oligopolies limit innovation-inducing competition. They sustain high markups, which are pure profits above the average cost, thus distorting economic efficiency. Oligopolies also collude on prices or quantities, further distorting markets. In resource-rich states, oligopolies are pervasive to varying degrees and contribute directly to limiting competition and, consequently, sustainable economic development and growth. A large number of resource-rich states have state-owned resource industries and large public sectors that control industries which are commonly monopolies or oligopolies. They cause a big loss in economic efficiency. In an economy-wide assessment, Tyers (2015) suggests that the full exploitation of oligopoly market power in Australia would cause a reduction of real GDP by as much as a third in the long run.

Subsidizing consumption widens the gap between actual prices paid at the market and prices set by producers, thus increasing the profits earned by oligopolistic industries. Moreover, oligopolies tend to be owned by the business elite who tend to influence or depend on the government (or the ruling class), as is evident in the case of the GCC states. Through these dynamics, oligopolies can interfere with market dynamics and economic policy through their power in the market and/or the policymaking process, advancing their own interests at the expense of economic growth and development.

To limit the role of oligopolies and enhance competition, the government can use regulation to ensure that oligopolies do not collude or set their prices above the average price of production. Competition policy refers "to government policy to preserve or promote competition among market players and to promote other government policies and processes that enable a competitive environment to develop" (UNCTAD 2009: 3). Various instruments can be used to implement competition policy, such as competition law, regulation of prices, competition advocacy, consumer protection, standards, intellectual property rights, international trade, investment, and licensing (UNCTAD 2009: 3).

Policy lessons are drawn in this chapter from illustrations from Kuwait and Chile. In Kuwait, like in many resource-dependent and GCC states, oligopolies capture a large part of efficiency in the economy and are highly distortionary. Shehabi $(2017,2019)$ shows that oligopoly markups capture a very large size of economic efficiency in the market. The expansion of exports of non-energy sectors is very limited in Kuwait mainly because oligopolies have few incentives to export internationally where they 
cannot sustain large markups as they do domestically (Shehabi 2019). Even in a low oil price environment and after reducing energy subsidies, the large size of oligopolies and their pure profits continue to entail limited expansion of trade and limited economic diversification effects in the export market of non-energy sector (reverse Dutch disease) dynamics (Shehabi 2019). Achieving sustainability thus requires oligopoly reform.

Competition and productivity reforms are an important example of a policy solution that promotes economic sustainability, as shown by Shehabi $(2017,2019)$ in model-driven assessments. These reforms improve the overall economic performance and restore the fiscal balance, and can accompany important sustainability-promoting reforms, such as energy subsidy reform, which alone is not sufficient to restore the fiscal balance (Shehabi 2017, 2019). Further, competition reform can yield substantial improvements in performance by reducing oligopoly markups. These reductions yield effects on overall economic activity that largely exceed the neoclassical gains in allocative efficiency from removing price distortions due to taxes, subsidies, and regulation (Shehabi 2017, 2019). Therefore, it has positive impacts of economic growth and fiscal sustainability both in the short and long runs.

Another example of successful industrial policy is a real-life example from Chile's forest resources and creating a competitive advantage in them. Chile, dubbed the "tiger" of Latin America, achieved large economic growth advancements owing to economic reforms of a military dictatorship government (Clapp 1995). For more than 60 years, Chile had very oligopolistic, inefficient, highly subsidized, and corrupt plantations and forest resources. It also had a high $75 \%$ reforestation subsidy established in 1974. Chile applied forest policy, a form of industrial policy, to create one of the world's most competitive forest resources at relatively low costs (Clapp 1995) within a brief period spanning approximately one generation. Government policies included state activism to promote forest expansions; state withdrawal through reduction of subsidies; privatization of the states' pulp mills and other parts of the industry; and guarantees against expropriations (Clapp 1995). These policies attracted foreign direct investments specifically to expand the forest resources industry. Combined with the opportunity of an increased forest products trade, the implementation of these policies enabled Chile to earn a comparative advantage in a new industry and export it. 


\section{Key Messages}

The chapter argues that economic sustainability in resource-rich states is not economic diversification only; rather, it is a process that pans out in the period during which revenue is dependent on an abundant yet exhaustible commodity, as well as in the subsequent period, when the commodity export revenue is depleted. The chapter offers a broader definition of economic sustainability that has two main perspectives, volatility and depletion, spanning both the short and long runs. It links economic sustainability in resource-dependent states to that of the drivers of economic growth through policies that focus on both the volatility and the depletion perspectives. Lessons are offered from successful examples of three different cases, namely Kuwait, Botswana, and Chile.

Successful growth-sustaining policies include a focus on appropriate management of resource windfall to achieve fiscal sustainability along with long-term diversification. Examples of successful policies include balancing capital investments between domestic and foreign markets, the design of countercyclical (rather than the oft-used pro-cyclical) fiscal policy, human capital investments, and avoiding boom-bust cycles by delinking spending from the volatility dynamics of resource export revenues. Successful experiences of Chile, Botswana, and Kuwait confirm the role of SWF assets in offering fiscal stabilization as well as long-term savings. Other examples include model-driven policy solutions that focus on the management of labor contracts for expatriate labor, improvements in institutional quality, and competition reform as important policy solutions for achieving economic sustainability. Notwithstanding implementation challenges, these policies were successful in achieving favorable economic performance because, as this chapter argues, they address both the volatility and the depletion challenges.

In addition to evidence from these real-case examples, achieving sustainability requires designing policies that also manage the trade-off between producing output today and leaving the resource in the ground for future production, as well as the trade-off between local consumption and exports of a given supply. Technology plays a pivotal role not only in creating new industries but also in transforming the resource industry into a more sustainable source that can overcome threats of depletion.

A key message here is that comparative advantage can be acquired, and not only restricted to the factor or product most abundantly available. This acquisition will in turn contribute to generating new sources of 
revenue that are diversified not only in the non-tradable but also in the exporting sectors. To that end, the growth-enhancing factors will help build new comparative advantages most importantly through technological advancements, human capital, industrial regulation, the political economy, and even the institutions, cultures, and mores needed for economic transformation.

Therefore, a key policy question for achieving sustainability in resourcedependent economies is how to best apportion investment into various components of financial, physical capital, and human capital assets. Sustainability-promoting policies are those that target enhancing the drivers of economic growth while addressing solutions for the volatility and the depletion perspectives, in both the short and long terms.

\section{Appendix 1: Classical Growth Model}

Under the Solow $(1956,1957)$ assumptions of full employment and a constant rate of labor force participation, the population growth rate $(n)$ matches the labor force and employment growth rates, as indicated in the following calculation:

$$
\frac{N_{t+1}-N_{t}}{N_{t}}=\frac{L_{t+1}-L_{t}}{L_{t}}=n
$$

Knowledge (being labor-augmenting technology; $\theta$ ) also grows at a constant exogenous rate $(g)$ where

$$
\frac{\theta_{t+1}-\theta_{t}}{\theta_{t}}=g .
$$

With a closed economy assumption absent government spending, output equals the sum of consumption and investment, and the equation of motion for collective capital stock is

$$
K_{t+1}-K_{t}=I_{t}-\delta K_{t}
$$


where the second term is depreciation at an exogenous and constant rate. ${ }^{14}$ Savings and investment decisions are exogenous, as are factor accumulation and technological growth, which represents one of the shortcomings of the original Solow approach. Employing a standard Cobb-Douglas production function, with both physical and human capital $(K)$, labor $(L)$, and labor-augmenting technology $(\theta)$, and ignoring for now the production factors of land and natural resources, constant returns to scale and diminishing marginal returns are

$$
Y_{t}=A K_{t}^{\alpha}\left(\theta_{t} L_{t}\right)^{\alpha-1}
$$

whereby $\theta L=L_{e}$, effective labor, and $0<\alpha<1$.

After some manipulation, the following is a corresponding equation of motion for output per effective worker with population growth:

$$
k_{e t+1}-k_{e t}=\frac{i_{e t}-(\delta+n+g) k_{e t}}{1+n+g}
$$

where $i_{e}$ is investment per effective worker, which is the savings rate times output per effective worker, expressed as $s f\left(k_{e}\right)$ where $f$ is the production function or the relationship between output and capital per effective worker. It follows that, multiplying all variables in the function by $1 / \theta \mathrm{L}$, yields the following corresponding function in terms of per effective worker:

$$
y_{e t}=A k_{e t}^{\alpha} .
$$

The steady state of capital per effective worker remains the same from one period to the next and is expressed as

${ }^{14}$ In the Mankiw et al. (1992) model, human capital is a separate factor of production represented by $H$ and grows in a manner whereby $H_{t+1}-H_{t}=I_{t}^{H}-d H_{t}$. 


$$
\begin{aligned}
& \frac{i_{e}}{1+n+g}=\frac{s y_{e t}}{1+n+g}=\frac{(\delta+n+g) k_{e t}}{1+n+g} \\
& =\frac{i_{b e}}{1+n+g}=\text { or } i=s f\left(k_{e t}\right)=i_{b e}=(\delta+n+g) k_{e t}
\end{aligned}
$$

where $i_{b e}$ is the break-even level of investment that maintains a constant level of capital per effective worker. Thus, in an economy growing at a steady state, in terms of per effective worker,

$$
s f\left(\overline{k_{e t}}\right)=(\delta+n+g) \overline{k_{e t}}
$$

where the steady state is

$$
\overline{i_{e}}=s A_{t} k_{t}^{\alpha}=\overline{i_{b}}=(\delta+n+g) \overline{k_{e t}} .
$$

This equation for the steady-state capital per effective worker can be solved in the following manner:

$$
\overline{k_{e}}=\left(\frac{s A}{\delta+n+g}\right)^{\frac{1}{1-\alpha}} \text {. }
$$

From this, the following relationships emerge between the population growth rate and real output per effective worker and real consumption per effective worker:

$$
\begin{gathered}
\overline{y_{e}}=A{\overline{k_{e t}}}^{\alpha}=\left(\frac{s A}{\delta+n+g}\right)^{\frac{\alpha}{1-\alpha}} A^{\frac{1}{1-\alpha}} . \\
\overline{c_{e}}=\overline{y_{e}}-\overline{i_{e}}=\overline{y_{e}}-s \overline{y_{e}}=\overline{y_{e}}(1-s)=(1-s)\left(\frac{A s}{\delta+n+g}\right)^{\frac{\alpha}{1-\alpha}} A^{\frac{1}{1-\alpha}}
\end{gathered}
$$

The standard approach is to show this steady state graphically, as in Fig. 7.5, where the steady-state levels of capital, consumption, and income per effective worker are 




Fig. 7.5 Steady-state growth and transition following a capital shock in the Solow model

$$
\overline{k_{e}}, \overline{c_{e}}, \overline{i_{e}}, \overline{y_{e}}=\overline{c_{e}}+\overline{i_{e}} \text {. }
$$

As such, aggregate variables of effective workers, capital, and output exhibit the same behavior growing at the same rate, as indicated in the following calculation:

$$
\frac{\partial \theta L}{\theta L}=\frac{\partial K}{K}=\frac{\partial Y}{Y}=(n+g+n g) \approx(n+g) .
$$

In the context of resource-rich states, to simulate the impact of commodity price volatility or conflict, a shock in the economy is first represented by a large destruction in capital $(\gamma)$ so that

$$
K_{t+1}=(1-\gamma) K_{t} \text {, where } 0<\gamma<1 \text {. }
$$

Initially, output will fall so that

$$
\frac{\Delta Y_{t+1}}{Y_{t}}=A(1-\gamma)^{\alpha}(n+g+n g)^{1-\alpha}<(n+g+n g) .
$$


The remaining capital falls short of the steady-state level, leaving investment at a level $\left(i_{e 1}\right)$ above its capital break-even point, causing growth to increase in the period following the war, as indicated in the following calculation:

$$
\frac{\Delta Y_{t+2}}{Y_{t+1}}=\frac{\Delta K_{t+2}}{K_{t+1}}=\frac{\delta+n+g}{s} \frac{(n+g+n g)^{1-\infty}}{(1-\gamma)^{1-\alpha}}-\delta>(n+g+n g) .
$$

This effect is enlarged if the saving rate also rises (see Fig. 7.5). The surplus of new investment is then over the break-even point and larger with an even faster recovery.

Thus, a temporarily contracting economy decreases the capital-to-labor ratio and raises capital per worker, increasing the productivity of capital and leading to temporarily higher growth rates in the reconstruction phase. Diminished returns eventually return as the long-term growth path is approached. If there is an accumulation of capital during the recovery (or reconstruction) phase, this recovery can be represented as a shift in the production possibility frontier curve. A speedy economic recovery post an economic shock may occur due to efficiency gains, represented normally as a movement along the production possibility or frontier curve. The shock (whether a drop in the resource price or a war) would typically have an impact on labor, increasing unemployment and decreasing the labor force and population.

Using a numerical simulation that represents a resource economy on the eve of a shock, the shock is simulated through a large negative shock to capital and a significant reduction in population, shown in Fig. 7.6.

Upon the end of the shock and at the commencement of recovery efforts, the capital-to-labor ratio converges to pre-shock levels and GDP grows at diminishing rates that are larger than pre-shocks levels to eventually converge with pre-shock growth levels, as Fig. 7.1 shows.

\section{Natural Resources and Technology}

Evaluating economic growth in the presence of depleted natural resources is consistent with the goals of achieving economic sustainability in resource-dependent economies. As the standard growth model, presented earlier, does not take into account natural resources as an input, the following representation examines growth in the presence of natural resources. 


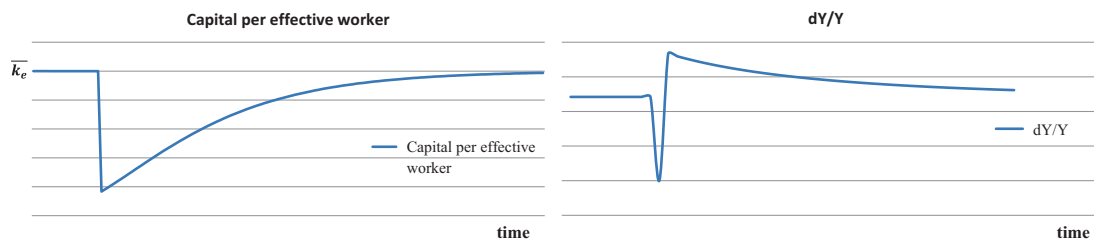

Fig. 7.6 Transition in capital per effective worker and growth rate following a shock to capital stock in the augmented Solow model

To demonstrate this, the total available quantity of a resource $(X)$ at a given time $t$ can be represented as $X_{t}$, while the quantity of the resource extracted can be expressed as $E_{t}$, so that $E_{t}=X_{t}$.

For simplification purposes, the other factors of production examined earlier will be ignored, assuming that the natural resource is the only input of production for now. The Cobb-Douglas production function can be expressed as

$$
Y_{t}=A E_{t}
$$

The assumption of constant technology can be relaxed and technology is now growing at a constant exogenous rate (g), expressed in (7.2). This set-up enables addressing the question of sustainability: what is the tradeoff between producing output today and leaving the resource in the ground for future production? Assuming the resource is extracted at a constant exogenous rate $(\varepsilon)$, so that

$$
E t=\varepsilon X t,
$$

the quantity of the resource remaining will decline exponentially over time, as follows:

$$
X_{t}=X_{0} e^{-\varepsilon t}
$$

The initial level of output will thus be

$$
Y_{0}=A_{0} \varepsilon X_{0} .
$$


It is thus clear that there is a positive relationship between the rate of extraction and output: a lower extraction rate will lead to a lower level of output. The growth rate of output can thus be expressed as the following, noting that this growth rate of extraction is the same as the growth rate of the resource stock:

$$
\frac{\partial Y}{Y}=\frac{\partial A}{A}+\frac{\partial E}{E}=(g-\varepsilon)
$$

This equation clearly shows that a higher extraction rate leads to a lower growth rate of output, which could even become negative at very high levels of extraction. Setting (7.20) equal to zero yields the extraction rate that is consistent with steady-state levels and a zero growth rate of output, which is

$$
g=\varepsilon^{*}
$$

$\varepsilon^{*}$ thus represents the sustainable level of output. Therefore, examining the levels of output in the economy can be determined by examining the extraction rate chosen in relation to $\varepsilon^{*}$. If it exceeds $\varepsilon^{*}$, the initial level of output will exceed the sustainable level, but will decrease over time, as Fig. 7.4 shows.

Importantly, including the remaining factors of production would complicate the algebraic representation but yield the same general conclusion.

\section{REFERENCES}

Aghion, P. and Howitt. P. (1992). A Model of Growth Through Creative Destruction. Econometrica 60(2), 323-351.

Aizenman, J., \& Riera-Crichton, D. (2014). Liquidity and foreign asset management challenges for Latin American countries. Commodity Prices and Macroeconomic Policy, 22, 91-134. Caputo, R. \& Chang, R. eds, Santiago: Central Bank of Chile.

Alexīv, M., \& Conrad, R. (2009). The elusive curse of oil. Review of Economics and Statistics, 91(3), 586-598. https://doi.org/10.1162/rest.91.3.586.

Auty, R. M. (1993). Sustaining Development in Mineral Economies: the Resource Curse Thesis. London: Routledge.

Auty, R. M. (2001). The political economy of resource-driven growth. European Economic Review, 45(4-6), 839-846. https://doi.org/10.1016/S0014-2921 (01)00126-X. 
Balassa, B. (1978). Exports and economic growth: Further evidence. Journal of Development Economics, 5(2), 181-189. https://doi.org/10.1016/03043878(78)90006-8.

Besada, H., \& O'Bright, B. (2018). Policy impacts on Africa's extractive sector: Botswana, diamond dependence, and diversification in the post-diamond period. Revue Gouvernance, 15(22), 86-105.

Bhagwati, J. (1978). Foreign trade regimes and economic development. Anatomy and Consequences of Exchange Control Regimes. Cambridge, MA: Ballinger for the National Bureau of Economic Research.

Black, G., \& LaFrance, J. (1998). Hotelling's Rule Relevant to Domestic Oil Production. Journal of Environmental Economics and Management, 36, 149-169.

Brazee, R. J., \& Cloutier, L. M. (2006). Reconciling Gray and Hotelling: Lessons from early exhaustible resource economics. American Journal of Economics and Sociology, 65(3), 827-856. https://doi. org/10.1111/\%28ISSN\%291536-7150/issues.

Bulte, E. H., Damania, R., \& Deacon, R. T. (2005). Resource intensity, institutions, and development. World Development, 33(7), 1029-1044. https://doi. org/10.1016/j.worlddev.2005.04.004.

Clapp, R. A. (1995). Creating competitive advantage: Forest policy as industrial policy in Chile. Economic Geography, 71(3), 273-296.

Collier, S., \& Sater, W. F. (1996). A History of Chile, 1808-1994. Cambridge: Cambridge University Press.

Collier, P. et al. (2010). Managing Resource Revenues in Developing Economies. IMF Staff Papers, 57, 84-118.

Corden, W. M. (1984). Booming sector and Dutch disease economics: Survey and consolidation. Oxford Economic Papers, 36(3), 359-380.

Corden, W. M., \& Neary, J. P. (1982). Booming sector and de-industrialisation in a small open economy. Economic Journal, 92(368), 825-848.

Corden, W. M. (2012). Dutch disease in Australia: Policy options for a three-speed economy. Australian Economic Review, 45(3), 290-304. https://doi. org/10.1111/j.1467-8462.2012.00685.x.

Davis, G. (1995). Learning to love the Dutch Disease: Evidence from the mineral economies. World Development, 23, 1765-1779.

Delacroix, J. (1977). The export of raw materials and economic growth: A crossnational study. American Sociological Review, 42, 795-808.

Frankel, J. A. (2011). A solution to fiscal procyclicality: The structural budget institutions pioneered by Chile (NBER Working Paper No. 16945). Cambridge, MA: National Bureau of Economic Research. Retrieved from https://ideas.repec. org/p/nbr/nberwo/16945.html

Gelb, A. H. (1988). Oil windfalls: blessing or curse? New York: Published for The World Bank [by] Oxford University Press.

Grossman, G. M. and Helpman, E. (1993). Endogenous Innovation in the theory of growth. Journal of Economic Perspectives, 8(1), 23-44. 
Heckscher, E. (1919). The effect of foreign trade on the distribution of income. Ekonomisk Tidskriff, 497-512. Translated as chapter 13 in American Economic Association.

Hotelling, H. (1931). The economics of exhaustible resources. The Journal of Political Economy, 39, 137-175.

IMF (International Monetary Fund). (2012). Botswana: 2012 Article IV Consultation. IMF Country Report, no. 12/234. Washington. D.C.: Author.

Jung, W. S., \& Marshall, P. J. (1985). Exports, growth and causality in developing countries. Journal of Development Economics, 18(1), 1-12. https://doi. org/10.1016/0304-3878(85)90002-1.

Karl, T. (1997). The paradox of plenty: Oil booms and petro-states. Berkeley, CA: University of California Press.

Krueger, A. O. (1984). Trade policies in developing countries. Handbook of International Economics, 1, 519-569. Jones, R. W. \& Kenan, B. P., eds, Elsevier. Retrieved from http://www.sciencedirect.com/science/article/pii/ S1573440484010145.

Lederman, D., \& Xu, L. C. (2007). Comparative advantage and trade intensity: Are traditional endowments destiny?. Natural Resources: Neither Curse nor Destiny. Lederman D. and Maloney, M. F. eds. Stanford: Stanford University Press.

Leontief, W. (1953). Domestic Production and Foreign Trade; The American Capital Position Re-Examined Proceedings of the American Philosophical Society, 97(4).

Lucas, R. E. (1988). On the Mechanics of Economic Development. Journal of Monetary Economics, 22, 3-42.

Maloney, W (2002). Missed opportunities: Innovation, natural resources and growth in Latin America. Economia, 3(1), 111-169.

Mankiw, N. G., Romer, D., \& Weil, D. N. (1992). A contribution to the empirics of economic growth. The Quarterly Journal of Economics, 107(2), 407-437.

Mehlum, H., Moene, K., \& Torvik, R. (2006). Institutions and the resource curse. Economic Journal, 116(508), 1-20.

Michaely, M. (1977). Exports and growth: An empirical investigation. Journal of Development Economics, 4(1), 49-53. https://doi.org/10.1016/03043878(77)90006-2.

Monzano, O., \& Rigobon, R. (2001). Resource curse or debt overbang? (NBER Working Paper No. 8390). Cambridge, MA: National Bureau of Economic Research. Retrieved from http://www.nber.org/papers/w8390.

Ohlin, B. (1933). Interregional and International Trade. Cambridge, MA: Harvard University Press, 1966.

Ossowski, R., Villafuerte, M., Medas, P. A., \& Thomas, T. (2008). Managing the oil revenue book: The role of fiscal institutions. IMF Occasional Papers, no. 260. Washington, DC: The International Monetary Fund (IMF).

Ramey, G., \& Ramey, V. (1995). Cross country evidence on the link between volatility and growth. The American Economic Review, 85(5), 1138-1151. 
Romer, P. M. (1986). Increasing Returns and Long-Run Growth. Journal of Political Economy, 94(5).

Romer, P. M. (1990). Endogenous Technological Change Journal of Political Economy, 98(5).

Sachs, J. D., \& Warner, A. M. (1995). Natural resource abundance and economic growth (NBER Working Paper No. 5398). Cambridge, MA: National Bureau of Economic Research. Retrieved from http://ideas.repec.org/p/nbr/ nberwo/5398.html.

Sala-i-Martin, X., \& Subramanian, A. (2003). Addressing the natural resource curse: An illustration from Nigeria (Working Paper No. 9804). Cambridge, MA: National Bureau of Economic Research. Retrieved from http://www. nber.org/papers/w9804.

Schumpeter, J. A. (1942, reprinted 1976). Capitalism, Socialism and Democracy. London: Routledge.

Shehabi, M. (2017). Assessing Kuwaiti energy pricing reforms. OIES Paper No. MEP 117. Oxford Institute for Energy Studies. Oxford, UK. DOI: 10.26889/9781784670931. https://www.oxfordenergy.org/wpcms/wpcontent/uploads/2017/11/Assessing-Kuwaiti-Energy-Pricing-ReformsMEP-17.pdf

Shehabi, M. (2018a). Maintaining the order: Contemporary Kuwaitisation dynamics and their historical perspectives. Gulfization of the Arab World, Exeter Critical Gulf Series, 1, 59-88. Jones M. O., Porter, R., \& Valeri, M. eds, Berlin: Gerlach Press.

Shehabi, M. (2018b). Success and failure in a petrostate: economic policy and performance in Kuwait since the Gulf War. https://doi.org/10.26182/5b $4 \mathrm{c} 0 \mathrm{~d} 3 \mathrm{~d} 38 \mathrm{~b} 2 \mathrm{~b}$.

Shehabi, M. (2019). Is energy subsidy reform in an oil-exporting small economy beneficial to trade? Illustrations from Kuwait. OIES Paper: MEP 21. Oxford Institute for Energy Studies. Oxford: UK. https://doi.org/10.26889/ 9781784671273.

Shehabi, M. (2020). Diversification effects of energy subsidy reform in oil exporters: Illustrations from Kuwait. Energy Policy, 123, 110966. https://doi. org/10.1016/j.enpol.2019.110966.

Solow, R. A. (1956). A contribution to the theory of economic growth. Quarterly Journal of Economics, 70(1), 65-94.

Solow, R. A. (1957). Technical change and the aggregate production function. Review of Economics and Statistics, 39, 312-320.

Swan, T. (1956). Economic growth and capital accumulation. Economic Record, 32(63), 334-361.

Tornell, A., \& Lane, P. R. (1999). The voracity effect. American Economic Review, 89(1), 22-46. https://doi.org/10.1257/aer.89.1.22.

Tyers, R. (2015). Service oligopolies and Australia's economy-wide performance. Australian Economic Review, 48(4): 333-356. 
Tyers, R., \& Walker A. (2016). Quantifying Australia's 'three-speed' boom. Australian Economic Review, 49(1), 20-43.

UNCTAD (United Nations Conference on Trade and Development). (2009). The Relationship between Competition and Industrial Policies in Promoting Economic Development. Geneva: UNCTAD Secretariat. https://unctad.org/en/Docs/ ciclpd3_en.pdf.

van der Ploeg, F. (2011). Natural resources: curse or blessing. Journal of Economic Literature, 49(2), June 2011.

van der Ploeg, F., \& Poelhekke, S. (2009). Volatility and the natural resource curse. Oxford Economic Papers, 61(4), 727-60.

van der Ploeg, F., \& Venables, A. J. (2012). Natural Resource Wealth: the Challenge of Managing a Windfall Annual Review of Economics, 4, 315-337.

Venables, A. J. (2016). Using natural resources for development: Why has it proven so difficult? Journal of Economic Perspectives, 30(1), 161-184.

Venables, A. J., \& van der Ploeg, F. (2010). Absorbing a Windfall of Foreign Exchange: Dutch Disease Dynamics (No. Discussion Paper No. 8086). London, UK: Centre for Economic Policy Research.

Wright, G., \& Czelusta, J. (2004). Why economies slow: The myth of the Resource Curse, Challenge, 47(2), 6-38. Published online 2014. https://doi.org/1 $0.1080 / 05775132.2004 .11034243$.

Open Access This chapter is licensed under the terms of the Creative Commons Attribution-NonCommercial-NoDerivatives 4.0 International License (http:// creativecommons.org/licenses/by-nc-nd/4.0/), which permits any noncommercial use, sharing, distribution and reproduction in any medium or format, as long as you give appropriate credit to the original author(s) and the source, provide a link to the Creative Commons licence and indicate if you modified the licensed material. You do not have permission under this licence to share adapted material derived from this chapter or parts of it.

The images or other third party material in this chapter are included in the chapter's Creative Commons licence, unless indicated otherwise in a credit line to the material. If material is not included in the chapter's Creative Commons licence and your intended use is not permitted by statutory regulation or exceeds the permitted use, you will need to obtain permission directly from the copyright holder. 